\title{
Relationship between BMI, Physical Activity, Zinc Serum with Fasting Blood Glucose in Diabetes
}

\author{
Amalia Purwandari ${ }^{1}$, JB Suparyatmo ${ }^{2}$, and Sugiarto ${ }^{3}$ \\ \{amaliapras385@student.uns.ac.id ${ }^{1}$,paryatmo@yahoo.com², sugiarto_sppd@yahoo.co.id $\left.{ }^{3}\right\}$ \\ 1,3 Postgraduate Nutrition Science Program, Sebelas Maret University, Surakarta, Indonesia \\ ${ }^{2}$ Staff Clinical Pathology Dr. Moewardi Hospital, Faculty of Medicine, Sebelas Maret \\ University, Surakarta, Indonesia
}

\begin{abstract}
The number of Diabetes Mellitus (DM) patients has been increasing. Several risk factors linked with Type 2 DM are overweight, lack of exercises and an unhealthy diet. The level of zinc serum DM patients is also lower than that of non DM and this is associated with poor blood glucose control. The research objective is to reveal the correlation between BMI (Body Mass Index), physical activity, level of zinc serum with level of fasting blood glucose on Type 2 DM. The research used a cross sectional design. The study sample was 34 Type 2 DM patients in 3 health centers in the city of Surabaya that were taken by consecutive sampling method. The Rank-Sprearman correlation test analysis revealed that there were correlations between physical activities $(\mathrm{p}=0,001, \mathrm{r}=0,592)$, zinc serum levels $(p=0,050, \quad r=0,339)$ with fasting blood glucose, and that there were no correlations between BMI $(p=0,680, r=0,073)$ and fasting blood glucose levels. It was concluded that the research revealed that there were correlations between physical activities, zinc serum, and fasting blood glucose, and that there were no correlations between BMI and fasting blood glucose of Type 2 DM patients.
\end{abstract}

Keywords: BMI, physical activities, zinc serum, fasting blood glucose.

\section{INTRODUCTION}

Epidemiological researches have shown tendency towards the increased number of incidence and prevalence of type $2 \mathrm{DM}$ worldwide, a trend that has become a global health issue [1]. In 2017, Indonesia ranked 6th and included in the top 10 countries for the number of people with diabetes with 10.3 million sufferers [2]. DM risk factors consist of unmodified risk factors such as age, race, ethnicity, family health record, gestational DM record and modifiable factors such as overweight, lack of physical activity, hypertension, dyslipidemia and an unhealthy diet [1]. Excessive or overweight BMI especially obesity is likely to be a cause of insulin resistance [3], so lifestyle modification, one of which focuses on diet and physical activity remains the cornerstone of Type 2 DM management [4].

Type $2 \mathrm{DM}$ is a multifactorial disease specifically related with energy metabolism, especially controlling carbohydrates and fats [5]. Some nutrients (other than carbohydrates) associated with blood glucose levels are: protein, fatty acids, vitamin D, vitamin $\mathrm{K}$, zinc, 
magnesium, chromium and sodium [6]. Zinc concentrations is significantly lower on diabetic than non-diabetics [7]. The lower zinc level on Type 2 DM patients is correlated with a higher prevalence of diabetes microvascular complications. Patients with lower zinc levels have worse glucose control and $\beta$ cell function [8]. This research is aimed at revealing the correlations between the Body Mass Index, physical activities, the level of zinc serum, and the level of fasting blood glucose of Type 2 DM patients.

\section{METHOD}

Conducted in February - March in some Puskesmas (Public Health Center) in Surabaya, the research used a cross sectional design. The population in this study was Type 2 Diabetes Mellitus patients who were members of Prolanis (Program Pengelolaan Penyakit Kronis/Chronic Disease Management Program) in 3 Public Health Centers in Surabaya namely Kalijudan, Rangkah and Pacarkeling Health Centers. The inclusion criteria of sample included: men and women, 30 - 60 years old of age, Type 2 DM patients without serious disease complications such as heart, kidney, and stroke and were willing to participate in research as evidenced by the agreement on informed consent. Exclusion criteria were samples of pregnancy, relocation and resignation. Data on the characteristics of the research subjects included age, education, occupation, and duration of suffering from DM obtained through interviews. Research variables included BMI, physical activity, serum zinc levels and fasting blood glucose levels.

The variables used are those previously researched variables, such as that of Adnan et al. [9] analyzing the correlation between IMT with blood glucose of diabetics, and that of Nurayanti and Adriani [10], and Azitha et al., the three of which analyzed the correlation between physical activities and blood glucose [11]. However, the risk of losing some nutrients on diabetics, especially micro nutrients must also be taken into consideration. One of the micro nutrients that is lower on diabetics compared to non-diabetics is zinc [7]. Thus, the research is aimed at analyzing the correlation between BMI, physical activities, and the zinc level of zinc serum and blood glucose on the same subjects, the type $2 \mathrm{DM}$ patients to control blood glucose level to avoid further complications. This research was approved by Health Research Ethics Committe of The Faculty of Medicine, Sebelas Maret University Surakarta. Subject who participated in this study had to sign an informed concent. The method of the research data sampling on those variables involve the following factors:

\subsection{Body Mass Index (BMI)}

BMI measurement is done by measuring body weight and height. Measuring weight uses tread scales with a capacity of $150 \mathrm{~kg}$ and accuracy of $0.1 \mathrm{~kg}$. Furthermore, measurement of height uses microtoise with of $0.1 \mathrm{~cm}$ accuracy. BMI is obtained through the formula: weight $(\mathrm{kg}) /$ height $\left(\right.$ meters $\left.^{2}\right)$.

\subsection{Physical activitiy}

Measurement of physical activity uses the PAL (Physical Activity Level) questionnaire through interviews. The components in the PAL questionnaire are activities that are carried out daily for 24 hours and consist of: general activities, transportation activities, household activities and other work related activities.

\subsection{Serum zinc levels}


The level of zinc serum analyzed using Atomic Absorption Spectrophotometer (AAS) method by means of a microwave digester. Patients' vena blood was taken $8 \mathrm{ml}$ and later was centrifuged to acquire a $3 \mathrm{ml}$ serum sample to analyze for the zinc level.

\subsection{Fasting blood glucose levels}

The analysis of the level of fasting blood glucose was $1 \mathrm{ml}$ venous blood taken in the morning after a minimally 8 hours of overnight fasting and was measured in $\mathrm{mg} / \mathrm{dl}$. The analysis used an automatic chemistry analyzer.

The data obtained were processed using SPSS 22 software covering the characteristics of the research subjects, data normality tests using Kolmogrov-Sminov and Rank-Spearman correlation test used to analyze the relationship between BMI, physical activity and serum zinc levels with fasting blood glucose levels due to abnormal data distribution.

\section{RESULT AND DISCUSSION}

The subjects of the research were 34 people of $36-60$ years old of age, whom were mostly female. Their education varied from uneducated to higher education graduates. Most subjects were housewives. The length of DM development is less than 1 year. Subjects' characteristics can be seen on table 1 .

Table 1. Characteristics of research subjects.

\begin{tabular}{llcc}
\hline \multicolumn{1}{c}{ Characteristics } & $\mathrm{n}$ & Number \\
\cline { 3 - 4 } Sex & Male & 1 & $\%$ \\
\cline { 2 - 3 } Age & Female & 33 & 2,9 \\
& & & 97,1 \\
& $30-49$ years & 13 & 38,2 \\
$\quad 50-60$ years & 21 & 61,8 \\
Education & 3 & 8,8 \\
$\quad$ Uneducated & 11 & 32,4 \\
$\quad$ Elementary School & 8 & 23,5 \\
$\quad$ Junior High School & 10 & 29,4 \\
$\quad$ Senior High School & 2 & 5,9 \\
$\quad$ University & 18 & 52,9 \\
Occupation & 8 & 23,5 \\
$\quad$ Housewife & 6 & 17,7 \\
$\quad$ Trader & 2 & 5,9 \\
$\quad$ Factory worker & & \\
Employee & 25 & 73,53 \\
DM Long Suffering & 9 & 26,47 \\
$\quad<5$ years & & \\
$\quad>5$ years & &
\end{tabular}

The average BMI of the study subjects was 27,17 and classified as obesity. Subject activities in this study are expressed in Physical Activity Level (PAL) with a mean of 1,62 which is classified as low activity. The mean value of serum zinc level 35,36 is included in the less category. Most subjects had blood glucose levels above normal with an average of 164,59 $\mathrm{mg} / \mathrm{dl}$ (table 2).

Table 2. Distribution of subjects based on BMI, physical activity, serum zinc levels and fasting blood glucose. 


\begin{tabular}{lccc}
\hline \multicolumn{1}{c}{ Variable } & Minimum value & Maximum value & Mean $\pm \mathrm{SD}$ \\
\hline BMI $\left(\mathrm{kg} / \mathrm{m}^{2}\right)$ & 17,1 & 40 & $27,17 \pm 4,42$ \\
Physical Activity $(\mathrm{PAL})$ & 1,41 & 1,9 & $1,62 \pm 0,12$ \\
Serum Zinc Level $(\mu \mathrm{g} / \mathrm{dl})$ & 5,8 & 83 & $35,36 \pm 22,31$ \\
Fasting blood glucose level $(\mathrm{mg} / \mathrm{dl})$ & 83 & 392 & $164,59 \pm 77,11$ \\
\hline
\end{tabular}

The results of data analysis showed that there were no significant correlations between BMI and fasting blood glucose $(\mathrm{p}>0,050)$. Physical activity and serum zinc levels are significantly associated with fasting blood glucose levels with the direction of a negative/inverse relationship, namely the lower physical activity and serum zinc levels the higher fasting blood glucose levels.

Table 3. Relationship between BMI, physical activity, serum zinc levels and fasting blood glucose levels.

\begin{tabular}{lcc}
\hline \multirow{2}{*}{ Variable } & \multicolumn{2}{c}{ Fasting blood glucose level } \\
\cline { 2 - 3 } & $\mathrm{r}$ & $\mathrm{p}$ \\
\hline BMI & $-0,073$ & 0,680 \\
Physical Activity & $-0,592$ & 0,001 \\
Serum Zinc Level & $-0,339$ & 0,050 \\
\hline
\end{tabular}

\subsection{Relationship between BMI and Fasting Blood Glucose Levels.}

The results showed that there was no significant relationship between BMI and fasting blood glucose levels $(r=-0.073, p=0.680)$. This is because IMT does not describe body fat distribution. Some references states that abdominal obesity is more closely related to increased fasting blood glucose levels compared to general obesity. A meta-analysis comparing BMI $\geq$ 30 and waist size $\geq 102 / 83$ concluded that a waist size $\geq 102 / 83$ is a better predictor than BMI in detecting diabetes development, especially on female. Central obesity is a more serious risk factor.[12].

Obesity is defined as BMI $>30 \mathrm{~kg} / \mathrm{m}^{2}$. However, as a parameter definer, BMI does not serve to differentiate fat free mass and fat mass and does not account for fat distribution. Obesity - related risk factors do not depend on obesity, but on the regional distribution of body fat excess. Furthermore, obesity may also trigger oxidative stress. In obesity, high levels of glucose or fat free mass circulating may increase the production of ROS (Reactive Oxygen Species), proven to reduce the expression insulin gene and insulin secretion [13].

\subsection{Relationship between Physical Activities and Fasting Blood Glucose.}

A statistical analysis showed a significant correlation between exercise and the level of fasting blood glucose $(r=-0.592, p=0.001)$, which is relevant to a research by Ngaisah [14] showing a significant correlation between the frequency of exercise with the level of blood glucose on a non-diabetes female group. A meta-analysis research by Boniol et al [15] to 56 studies stated that the increase of exercise was related with the significant decrease of fasting blood glucose and HbAlc. The 100 minute increase of exercise per week was related with $4.71 \mathrm{mg} / \mathrm{dl}$ decrease of fasting blood glucose on type $2 \mathrm{DM}$ and prediabetes.

A recommended physical activity for Type 2 DM patients is daily physical activity and physical exercise that is carried out regularly 3-5 times a week for 30-45 minutes with a total of 150 minutes per week. The gap between exercises is no more than 2 consecutive days. Daily activities or daily activities are not included in physical exercise but are still encouraged to be active every day [1]. 
The research subjects were mostly housewives above 50 years old of age with a category of activity including low, while the results of the fasting blood sugar level examination were mostly high, with an average of $164 \mathrm{mg} / \mathrm{dl}$. Sports activities carried out are gymnastics and carried out once a week on Prolanis gymnastics activities. According to Ngaisah [14], there is a relationship between low exercise activity as a risk factor for diabetes mellitus. The duration of exercise is most closely related to blood glucose status, followed by aspects of exercise routine and frequency.

\subsection{Relationship between Zinc Serum Levels and Fasting Blood Glucose.}

The results of the statistical analysis showed that there was a significant relationship between serum zinc levels and fasting blood glucose levels $(r=-0,339, p=0.050)$ and negatively correlated or inversely proportional. These results are consistent with Bandeira et al [16] it 's study that patients with Type 2 DM with blood zinc status who showed poor glycemic control and Lou et al [8] who stated that patients with lower zinc levels might have diabetes duration longer, worse glycemic control and worse $\beta$ cell function.

Zinc is vital to cell $\beta$, insulin action, glucose homeostasis and diabetes pathogenesis along with their complications [17]. Zinc is also important to pancreas to control the level of blood glucose. Insulin is stored in crystals as insulin-zinc complex. Thus, the concentration of zinc cell $\beta$ pancreas is the highest in the body. Sufficient zinc supply is highly significant to the biosynthesis of insulin and its storage, especially should hyperglycemia occur [18]. Hyperglycemia lowers zinc level and increases excretion of urine due to interference in zinc reabsorption through kidneys. [19]. Human's zinc concentration is tightly regulated and the correlation between zinc homeostasis interference and diabetes mellitus is marked with high blood glucose concentration as a result of secretion decline and insulin action [20].

Significally lower zinc concentration on DM patients than non-DM is unrelated with the lower zinc intake. The duration of DM is also an impact on zinc concentration in the blood [7]. Type $2 \mathrm{DM}$ is characterized by significant loss of important micronutrients because of the basis of disease metabolites and their complications. Several changes in the level of micronutrient substance may impose negative impacts on glucose homeostasis and insulin sensitivity on type $2 \mathrm{DM}$ and may also start disease complications [21].

\section{CONCLUSION}

The research concluded that there was a significantly negative correlation between physical activities and levels of zinc serum with fasting blood glucose. The less frequent of physical activities and lower levels of zinc serum, the higher the fasting blood glucose gets. Furthermore, there was no significant correlation between BMI (Body Mass Index) and fasting blood glucose of type 2 Diabetes Mellitus patients. Due to the exclusion of waistline measurement to determine obesity, a comparison between general obesity and central obesity to find which of them is more related with the level of blood glucose is not available.

The research result provided some recommendations for type 2 DM patients such as performing physical activities as suggested by PERKENI (Association of endocrinologists of Indonesia) involving a $3-5$ times per week exercise for $30-45$ minutes of totally 150 minutes per week, as well as controlling their body weight to avoid central obesity to keep their blood glucose normal. It is also necessary that zinc check be done on type 2 DM patients to prevent further complications due to zinc deficiency by for instance giving supplements. 


\section{REFERENCES}

[1] PERKENI, Pengolahan dan Pencegahan Diabetes Melitus Tipe 2 Di Indonesia 2015. 2015.

[2] IDF, Eighth edition 2017. 2017.

[3] B. E. Levin, A. A. Dunn-meynell, V. H. Routh, E. Barry, A. A. Dunn-meynell, and H. Vanessa, "Obesity and Diabetes," vol. 28, pp. 138-143, 2013.

[4] M. A. Via and J. I. Mechanick, "Nutrition in Type 2 Diabetes and the Metabolic Syndrome," Med. Clin. North Am., vol. 100, no. 6, pp. 1285-1302, 2016.

[5] R. Valdés-Ramos, G. -López, A. Laura, M.-C. Beatriz, E. And Benítez-Arciniega, and A. Donají, "Send Orders for Reprints to reprints@benthamscience.ae Vitamins and Type 2 Diabetes Mellitus," Endocrine, Metab. Immune Disord. Targets, vol. 15, pp. 54-63, 2015.

[6] Z. Sun, "Negative pressure therapy: theory and practice," Diabetes. Metab. Res. Rev., vol. 26, no. 6, pp. 446-447, 2010.

[7] J. C. Fernández-Cao, M. Warthon-Medina, V. Hall Moran, V. Arija, C. Doepking, and N. M. Lowe, "Dietary zinc intake and whole blood zinc concentration in subjects with type 2 diabetes versus healthy subjects: A systematic review, meta-analysis and metaregression," J. Trace Elem. Med. Biol., vol. 49, pp. 241-251, 2018.

[8] Y. Y. Luo, J. Zhao, X. Y. Han, X. H. Zhou, J. Wu, and L. N. Ji, "Relationship between serum zinc level and microvascular complications in patients with type 2 diabetes," Chin. Med. J. (Engl)., vol. 128, no. 24, pp. 3276-3282, 2015.

[9] M. Adnan, T. Mulyati, J.K. Iswono, "Hubungan Indeks Massa Tubuh (IMT) dengan kadar gula darah penderita Diabetes Mellitus (DM) tipe 2 Rawat Jalan di RS Tugurejo Semarang," Jurnal Gizi Universitas Muhammadiyah Semarang, vol 2, no 1, 2013.

[10] L. Nurayati and M. Adriani, “Association Between Physical Activity and Fasting Blood Glucose Among Type 2 Diabetes Mellitus patients," Amerta Nutr., vol 1, pp. 8087, 2017.

[11] M. Azitha, D. Aprilia, Y.R. Ilhami, "Hubungan aktifitas fisik dengan kadar glukosa darah puasa pada pasien Diabetes Mellitus yang datang ke Poliklinik Penyakit Dalam RS M Djamil Padang," Jurnal Kesehatan Andalas, vol. 7, no. 3, pp. 400-404, 2018.

[12] D. C. Seo, S. Choe, and M. R. Torabi, "Is waist circumference $\geq 102 / 88 \mathrm{~cm}$ better than body mass index $\geq 30$ to predict hypertension and diabetes development regardless of gender, age group, and race/ethnicity? Meta-analysis," Prev. Med. (Baltim)., vol. 97, pp. 100-108, 2017.

[13] P. Manna and S. K. Jain, "Obesity, Oxidative Stress, Adipose Tissue Dysfunction, and the Associated Health Risks: Causes and Therapeutic Strategies," Metab. Syndr. Relat. Disord., vol. 13, no. 10, pp. 423-444, 2015.

[14] RADEN RORO DEWI NGAISYAH, "Hubungan Asupan Kromium Dengan Tingkat Gula Darah Pada Anggota Persadia Samarinda Tahun 2010 Tesis Raden Roro Dewi Ngaisyah Fakultas Kesehatan Masyarakat Depok," Fak. Kesehat. Masy. Progr. Stud. Ilmu Kesehat. Masy., 2010.

[15] M. Boniol, M. Dragomir, P. Autier, and P. Boyle, "Physical activity and change in fasting glucose and HbAlc: a quantitative meta-analysis of randomized trials," Acta Diabetol., vol. 54, no. 11, pp. 983-991, 2017.

[16] S. A. Lottenberg et al., "Association of reduced zinc status with poor glycemic control in individuals with type 2 diabetes mellitus," J. Trace Elem. Med. Biol., vol. 44, pp. 132 136, 2017.

[17] P. Ranasinghe, S. Pigera, P. Galappatthy, P. Katulanda, and G. R. Constantine, “Zinc 
and diabetes mellitus: Understanding molecular mechanisms and clinical implications," DARU, J. Pharm. Sci., vol. 23, no. 1, pp. 1-13, 2015.

[18] V. A. Pirogov, E. S. Reizin, and B. D. Tartakovskii, "Matching Layers for Electroacoustic Receiving Transducers.," Sov Phys Acoust, vol. 19, no. 5, pp. 478-481, 1974.

[19] L. V. Pires, G. B. de Carvalho, P. N. Brandão-Lima, C. S. C. Maia, and K. B. F. Barbosa, "Zinc's role in the glycemic control of patients with type 2 diabetes: a systematic review," BioMetals, vol. 30, no. 2, pp. 151-162, 2017.

[20] J. Jansen, W. Karges, and L. Rink, "Zinc and diabetes - clinical links and molecular mechanisms," J. Nutr. Biochem., vol. 20, no. 6, pp. 399-417, 2009.

[21] B. Kaur and J. Henry, Micronutrient status in type 2 diabetes: A review, 1st ed., vol. 71. Elsevier Inc., 2014. 